\title{
ResearchArticle
}

\section{Estimates of combining ability, yield and yield components in Indian mustard (Brassica juncea L.)}

Nagendra Maurya and A.K. Singh

\section{SUMMARY}

Combining ability analysis of $10 \times 10$ diallel set of crosses in Indian mustard for ten quantative traits revealed preponderance of non-additive gene effects for plant height, number of primary branches per plant and seed yield per plant, whereas additive gene effect was found to be predominant for the inheritance of rest of the character. The parent Varuna, RH-3904 and RH-819 were the good general combiners for seed yield and oil content. Varuna and RH-819 also exhibited desirable general combining ability effect for earliness and dwarfness. Among the cross combination, cross Varuna $\times$ RH -819 exhibited superior specific combiningability effect for days to 50\% flowering, number of secondary branches per plant and other yield attributing traits. Most of the cross involving high-low general combining parent, exhibited high sca effect for various traits. Seed yield was highly, significantly and positively correlated with days to $50 \%$ flowering, plant height, number of primary branches per plant, length of siliqua, and test weight. Hence, selection for the higher values of these traits will be desirable to increase seed yield.

Key Words : Brassica juncea, General combining ability, Specific combining ability, Correlation, Seed yield

How to cite this article : Maurya, Nagendra and Singh, A.K. (2018). Estimates of combining ability, yield and yield components in Indian mustard (Brassica juncea L.). Internat. J. Plant Sci., 13 (1): 71-75, DOI: 10.15740/HAS/IJPS/13.1/71-75.

Article chronicle : Received : 13.06.2017; Revised : 19.11.2017; Accepted : 02.12.2017

\section{MEMBERS OF THE RESEARCH FORUM}

Author to be contacted :

Nagendra Maurya, Department of Genetics and Plant Breeding,

Tilakdhari College, Jaunpur (U.P.) India

Email : nagendraphd@yahoo.com

Address of the Co-authors:

A.K. Singh, Department of Genetics and Plant Breeding, Tilakdhari

College, Jaunpur (U.P.) India 